\title{
The False Promise of Human Rights-Based Approach to Freedom of Information Laws
}

\author{
Dang Trung Ha
}

Ph.D. Candidate

Griffith Law School 0.12 Law Building N61

Griffith University Nathan QLD 4111, Australia

Email: ha.dangtrung@griffithuni.edu.au

\begin{abstract}
This article explores a normative ideal of human rights-based approach ('HRBA') to Freedom of Information ('FOI') laws and why it has failed in practice in many countries. Arguably, a HRBA, which stresses the intrinsic values of a right to access state-held information, is claimed as an essential approach to drafting of FOI laws. However, the approach cannot operate in a vacuum, and its adoption should depend on local political, economic, and cultural contexts. Instrumentalism links FOI laws to the function of a tool for accountability, effect of public administration or globalisation led to a deficit of common principles agreed to for FOI laws and does not go far enough in protecting the right of access to state-held information as a human right.
\end{abstract}

Keywords: Freedom of Information, Human Rights, Accountability, Public Administration, Globalisation.

Reference to this paper should be made as follows: Dang, T.Ha (2017) 'The False Promise of Human Rights-Based Approach to Freedom of Information Laws', Int. J. Human Rights and Constitutional Studies, xxx

Biographical notes: Graduating from Faculty of Law (Vietnam National University) and then completing Master of International Economic Law at University of Canberra (Australia), Dang Trung Ha has worked for the Government of Vietnam for about 15 years as a legal expert in the fields of human rights and international laws. Since 2014, he is a PhD Candidate at Griffith Law School, Australia. His thesis explores whether Vietnam - where both economy and society are experiencing transitions under the socialist single-party system - can adopt and implement a FOI law in order to ensure the right to access state-held information. This article is a part of this ongoing research-project. 


\title{
Dang Trung Ha
}

\section{$1 \quad$ Introduction}

After an era of being regarded as a 'luxury' regime reserved for the rich and longstanding democratic countries only [Roberts (2006), p. 14], FOI law ${ }^{1}$ has now spread to more than one hundred countries (Freedominfo.org). According to Ackerman and SandovalBallesteros, FOI law is a legal document to guarantee the right to access information held by public bodies:

\begin{abstract}
A FOI law gives citizens, other residents, and interested parties the right to access documents held by the government without being obliged to demonstrate any legal interest or 'standing.' Under an FOI law, government documents are assumed to be public unless specifically exempt by the law itself, and individuals can access them without explaining why or for what purpose they need them [Ackerman and SandovalBallesteros (2006), p. 93].
\end{abstract}

FOI law stresses a shift from the 'need to know', which requires citizens who want state-held information to provide the reason 'for what purpose they need them', to a 'right to know', which allows them to make a request without any reasons (Sebina, 2006). Although the phrase 'FOI' contains the term 'freedom', it does not stand for the 'negative freedom' from censorship [Berlin (1958), p. 369], but it is a positive right to obtain information that is held by public authorities (Birkinshaw, 2006; Worthy, 2017). Darch and Underwood (2009, p.4) state that FOI has the characteristics of a 'claim right' under the categories suggested by Hohfeld, which requires the public bodies to 'respect, protect and fulfil' the right to access state-held information.

Despite the fact that the United Nations ('UN') failed to gain the consensus of its members on the drafts of the Convention on Freedom of Information in 1949 [Donders (2015), p. 10], there is a growing consensus accompanied by significant evidence that access to state-held information should be conceptualised as a human right. Starting from this point, this article examines the theoretical features of HRBA to FOI laws and why this universal theory has been resisted in practice.

\section{Human rights-based approach: a normative ideal to FOI laws}

\subsection{The recognition of FOI as a human right}

The right of access to state-held information has consistently been conceptualised as a human right in three different ways, being: (a) an integral part of freedom of expression; (b) a supporting right; (c) an independent human right.

First, the argument that FOI is a part of freedom of expression springs from the efforts and practices of interpreting and implementing the right of 'freedom to seek, receive' information under Articles 19 of the International Convention on Civil and Political Rights 1966 ('ICCPR')" or Article 13 of the American Convention on Human Rights('ACHR') 3 . In 2006, the Inter-American Court of Human Rights stated under Claude Reyes $v$ Chile that 'the Convention [ACHR] protects the right of all individuals to request access to state-held information'. ${ }^{4}$ In 2011, the United Nations Human Rights 
Council ('UNHRC') clearly identified that 'Article 19, paragraph 2 [ICCPR] embraces a right of access to information held by public bodies' (Human Rights Committee, 2011).

Second, FOI should be considered as a prerequisite for the implementation of other fundamental human rights. McDonough (2013) stated that access to information is necessary to the right to take part in public affairs, the right to privacy, the right to a fair trial, the right to life and other economic and social rights. Bishop (2011) conceptualized access to information as a human right on the basis of the relationship between this right and 'emerging' rights including the right to a healthy environment and the right to truth. Florini (2007) [Florini (2007)] argued the disclosure of state-held information possibly strengthens the social and economic rights such as the right to education and the right to food. The Article 19 Organisation (2007, p.17) argues that access to state-held information 'is not only a right in itself, but a tool for exercising other rights'.

Third, a number of scholars and experts argue access to state-held information contains moral values of individuals and thus should be recognised as a human right. According to Birkinshaw (2006, p.47), access to state-held information is a human right because state bodies 'act on our account and in our name'. Pursuant to Mathiesen (2008), access to state-held information deserves a position as a human right because access to information is 'a resource necessary for living a minimally good life'. McDonagh (2013) approached the intrinsic value of access to information when making the argument that the right to information is essential for democratic societies. The United Nation Special Rapporteur Frank La Rue called for the necessary recognition of access to state-held information as the 'right in and of itself':

The Special Rapporteur wishes to state again that the right to seek, receive and impart information and ideas of all kind, regardless of frontiers, and through any media of his or her choice, set forth in Article 19 of the Universal Declaration of Human Rights, and reiterated in Article 19(2) of the International Covenant on Civil and Political Rights, is not merely a corollary of freedom of opinion and expression: it is a right in and of itself (La Rue, 2011).

\subsection{The obligations of states}

Human rights raise both positive and negative obligations for states (Shue, 1996). The positive obligation is often emphasised because the right to access information will not be implemented if state agencies, which hold the information, do not perform their duties responsibly (Darch and Underwood, 2009). Individuals can exercise their rights to make requests to access information only if public authorities are obligated to respond to such requests. Therefore, access to information can only be assumed when legislation creates mechanisms that oblige public bodies to disclose information. This State obligation has been recognised by the UNHRC in General Comment No. 34, which provides:

To give effect to the right of access to information, states parties should proactively put in the public domain Government information of public interest. States parties should make every effort to ensure easy, prompt, effective and practical access to such information. States parties should also enact the necessary procedures, whereby one may gain access to information, such as by means of freedom of information legislation [Human Rights Committee (2011), para 18]. 


\section{Dang Trung $\mathrm{Ha}$}

In Özgür Gündem v Turkey, the European Court of Human Rights ruled in favour of the positive obligation of the state so that 'effective exercise of this freedom does not depend merely on the state's duty not to interfere, but may require positive measures of protection.' 5 In Claude Reyes $v$ Chile, the IACHR gave its clear view as to the positive obligations of the state that 'Article 13 of the Convention [ACHR] should be understood as a positive obligation on the part of the state to provide access to the information it holds'. 6

The positive obligation implies that states must ensure the public's access to a maximum of state-held information and set out responsibilities for the public authorities to provide information proactively, particularly in relation to decisions which have been made and have a direct influence on people's lives. The state also has obligations to make a maximum effort to ensure that the information is accessible through the easiest, most opportune and convenient processes. The fee that the information-requesting parties have to pay for being provided with information must be regulated reasonably and acceptably. Maximum implementation of access to state-held information requires the information-providing parties (the public bodies) to act in good faith when dealing with requests for information made by individuals (Organization of American States, 2012).

\subsection{The universal value}

Human rights, though its concept was primarily defined as an achievement of Western liberty, are popular themselves because of the shared human nature and the universal values of morality, compassion and tolerance, which are characteristics honoured across all cultures [Freeman (2011), pp. 56-57]. The universal values of human rights derive from the very nature of human beings, 'not something that is either earned or can be lost' [Donnelly (2007), p.282]. Boutros-Ghali (1995), the former Secretary-General of the United Nations, conceives of human rights as 'a global language of all humanity'. Advocates for the recognition of FOI as a human right attest to its noteworthy position in the cause of affirming universal values of the freedom of access to information. There is a logical consequence: human rights carry universal values; access to state-held information is a human right, so access to state-held information enshrines universal values (Darch and Underwood, 2009).

Arguments against the universality of human rights are still emerging, especially from Asian countries. Among the prevailing notions, there are two notable points that affect the guarantee of access to information. The first point that will be argued by some Asia leaders is that economic development will only succeed under a dictatorship regime and hence the demand for the right of access to information is not a priority and may interfere with economic development (Rodan, 2004). According to this perception, the right to development (in economic terms) of a country should be given priority over the rights of individuals, that 'individuals must put the state's rights before their own' [Copper (1994), p. 69]. The second is based on the belief in cultural differences between Western and Eastern countries. According to this point of view, nations have different histories, cultures, religions, and economic development levels, so the degree to which human rights and freedoms are implemented must also be different. Human rights, therefore, cannot carry only universal value but must bear relative value (Sen, 1997). 
The debate over the universality and relativity of human rights continues and is a complex topic (Renteln, 2013). Nevertheless, the eighth declaration in the Vienna Declaration and Program of Action, which was adopted by the World Conference on Human Rights in Vienna on 25 June 1993, shows consensus between countries on obligations to enforce human rights despite local context:

\begin{abstract}
Democracy, development and respect for human rights and fundamental freedoms are interdependent and mutually reinforcing. Democracy is based on the freely expressed will of the people to determine their own political, economic, social and cultural systems and their full participation in all aspects of their lives. In the context of the above, the promotion and protection of human rights and fundamental freedoms at the national and international levels should be universal and conducted without conditions attached (Vienna Declaration)
\end{abstract}

\title{
2.4 Human rights standards for the right to FOI
}

\subsubsection{The right for everyone}

The HRBA suggests that access to information as one integral part of the freedom of expression should encompass 'everyone' in accordance with Article 19 of the ICCPR. The recognition of FOI as an independent right in the Council of Europe Convention on Access to Official Documents also results in the definition of access to state-held information as 'the right of everyone'. HRBA insists on the implementation of the right to access information 'without distinction of any kind...or other status' (ICCPR, Art.2). Thus, conceptualising access to state-held information as a human right enables the definition that is the right of 'everyone' rather than just being granted to the citizens or residents by the FOI laws in a number of countries (Ackerman and Sandoval-Ballesteros, 2006).

\subsubsection{Broad interpretation of state-held information}

The formality of state-held information derives from functions of public authorities and is associated with state power. The information held by public authorities must therefore be stored in certain forms so that it is accessible. These forms include records, documents, dossiers, drafts, instructions communicated verbally in meetings from the leaders of public agencies, information stored on floppy disks, memory cards, tapes, video tapes or any other forms of electronic devices.

There are increasingly broad definitions of state-held information under international conventions (Bouhadana, 2016). For example, the Aarhus Convention on access to information, public participation in decision-making and access to justice in environmental refers to 'any information in written, visual, aural, electronic or any other material form' (Art.2). Similarly, the definition of public documents under the Council of Europe Convention on Access to Public Documents includes 'all information recorded in any form, drawn up or received and held by public authorities' (Art.2). 
Dang Trung Ha

\subsubsection{Broad view of the scope of the 'public bodies'}

The General Comment No. 34 of the UNHRC states that 'public bodies' should include '[a]ll branches of the state (executive, legislative and judicial) and other public or governmental authorities, at whatever level' [Human Rights Committee (2011), para 7]. The Council of Europe Convention on Access to Official Documents provides the explanation that state agencies means:

1. Government and administration at national, regional and local level;

2. Legislative bodies and judicial authorities in so far as they perform administrative functions according to national law;

3. Natural or legal persons in so far as they exercise administrative authority (Art.1).

None of these provisions contains exceptions which could help a state body be exempted from the obligations of public disclosure. The HRBA suggests a firm underlying foundation for re-examining the 'absolute exemptions' of certain state bodies under several FOI laws around the world. ${ }^{7}$

\subsubsection{Three conditions of limitation}

A controversial topic in the discourse regarding the recognition of human rights is about how to balance the parties' interests and what principles are important when determining the restrictions upon the emerging rights. Mill (1869) wrote that freedom of an individual should be limited only if it directly encroached on the freedom of another or on the public interest. His point of view was embedded into the Universal Declaration of Human Rights 1948, which states that the purpose of rights limitations are for 'securing due recognition and respect for the rights and freedoms of others and of meeting the just requirements of morality, public order and the general welfare in a democratic society'(Art.29).

It is clear that applying the principle to the cause of limiting human rights in a justifiable way is not simple. A variety of terms in the text of Article 29 of the Universal Declaration of Human Rights 1948 need clarifying, such as 'morality', 'public order', 'the general welfare', 'democratic society' and so on. It can be seen that the general clauses on limitation of rights, though differently expressed in international treaties, are all based on three conditions:

Paragraph 3 [of the Article 19 of the ICCPR] lays down specific conditions and it is only subject to these conditions that restrictions may be imposed: the restrictions must be 'provided by law'; they may only be imposed for one of the grounds set out in subparagraphs (a) and (b) of paragraph 3; and they must conform to the strict tests of necessity and proportionality [Human Rights Committee (2011), para 22].

The first condition: provided by law

By this condition, the state cannot refuse to provide information by the simple excuse of not yet having a law or legal regulations on public disclosure. According to the UNHRC, the 'law' limiting the right must include sections on circumstances in which the right is 
limited so that the individual is informed about these limitations [Human Rights Committee (2011)], para 25). The European Human Rights Court defines the phrase 'prescribed by law' as comprising three components: (1) The restriction of the right must be based on domestic legislation; (2) The domestic legislation must be accessible; and (3) The expression of the legislation must be clear and understandable [Clayton et al. (2000), p. 383].

The first condition contributes an important basis for people to demand their right of access to state-held information in countries which have not yet enacted FOI legislation. Accordingly, these countries cannot limit the right with the excuse that their domestic law on information provision does not yet exist.

The second condition: legitimate aim of limitation

Under Paragraph 3, Article 19 of the ICCPR, there are two catalogues of circumstances that a member state may use to limit the right to freedom of expression, which are:

(a) For respect of the rights or reputations of others; and

(b) For the protection of national security or of public order (order public), or of public health or morals. (Art. 19 (3) of the ICCPR.)

The section (b) is often used as a justification to limit the right to access state-held information. Accordingly, much documentation cannot be disclosed if it has been categorized as 'state secrets', which may affect national security or public interest. However, regulations on state secrecy will be unfit if its hinder journalists, researchers, environmental activists and human rights defenders from their freedom of expression.

The third condition: necessity and proportionality

The UNHRC refers to the principle of proportionality in its General Comments No.34 on freedom of expression, which requires that any limitation on the right 'must conform to the strict tests of necessity and proportionality' [Human Rights Committee (2011)]. With an effort to define the principle of proportionality, Barak proposes a four-step test of proportionality, comprised as follows:

- Identify the proper purpose or legitimate aim of the limitation;

- Determine the rational connection between a restriction and a right;

- Determine the necessity of measures to limit the right for achieving legitimate purpose;

- Fairly balance the interests of and the losses from the right restriction.

This four-step test has theoretical and practical value in determining the scope and limits of FOI when being recognized as a human right. The proportionality principle importantly examines the balance between the benefits likely brought in by the rights restriction and the losses caused by such legal limitation [Barak (2012), p. 340]. This mechanism, also known as 'public interest tests' (ARTICLE 19 1999), implies that competent state agencies consider the indispensable protection of the public interest and the legitimate interests of FOI and limit the right only when there is obvious evidence showing that the public benefit outweighs the legitimate interests of FOI. 
Dang Trung $\mathrm{Ha}$

\section{Instrumental grounds: a reality of FOI laws}

\subsection{Historical development of FOI laws}

The first law on FOI was enacted in Sweden in 1766 and provided for the right of Swedish citizens to 'have free access to official documents' (The Freedom of the Press Act, Art. 1). The introduction of this regime, however, did not stem from the need to protect access to information but was influenced by Chinese practices of governance (Mustonen, 2006). According to Anders Chydenius, who was known as the leading classical liberalist of Nordic history, China under the Ch'ing Dynasty was governed in accordance with Confucian philosophy, whereby the executive apparatus operated in the most transparent manner to enable freedom of the press. This resulted in the Ch'ing Dynasty's success in effectively governing the country (Mustonen, 2006). The Swedish FOI law linked the right to access information held by public bodies to the freedom of the press in order to ensure government operations were under the strict oversight of the public, and to improve the efficiency of state governance (Mustonen, 2006).

It then took a long time for the world to witness the adoptions of other laws in respect to FOI. The second was enacted in Finland approximately two hundred years after Sweden's first FOI Law. By 1990, thirteen countries has enacted laws on FOI: Finland (1951), the US (1966), Norway (1970), France and the Netherlands (1978), Australia and New Zealand (1982), Canada (1983), Columbia (1985), Greece (1986), Denmark and Austria (1987) and Italy (1990). As summarised by Roberts, the visibly shared characteristics of these countries include wealth and a long history of democracy and the development of systems of civil society organizations [Roberts (2006), p. 107]. Bennett argues that the demand for enhanced accountability were prerequisites for these states to pass FOI laws (Bennett, 1997).

These pre-conditions were not present in many countries which enacted their FOI laws after 1990. The nearly one hundred countries which promulgating the law on FOI from 1991 to 2017 have diverse characteristics with respect to levels of economic development and organisational forms of state apparatus. Stubbs pointed out major differences in politically and socially contextual conditions of countries with FOI laws enacted after 1990 in addition to their diversified economies [Stubbs (2012), p. 73]. Banisar (2006) described four reasons why FOI laws have been adopted in contextually different countries since 1990s, including the pressure of international organisations on developing states, the increase in the demand for information in modern society, to prevent corruption and scandals and the recognition of FOI as a human right.

The trend of recognising access to information in constitutions is important for the passage of FOI law as a legal tool to protect this constitutional right (Banisar, 2006). However, the rights-based rationale for a passage of FOI law needs to adapt with other purposes, including enhancing accountability, effecting for administrative apparatus or serving for globalisation's requirement. 
The false promise of HRBA to FOI laws

\title{
3.2 Instrumental approaches to FOI laws
}

\subsubsection{FOI law as a requirement for public scrutiny and accountability}

The literature shows that FOI law as a tool of enhancing public scrutiny and accountability was a significant driver for the enactment of FOI laws in a number of developed countries before the 1990s (Bayne [Bayne (1984)], 1984; Bennett, 1997; Hazell, 1989; Xiao, 2013). The rationale is rooted in the philosophy of Bentham, which suggest that all activities undertaken by a government must be supervised by 'public eyes', and 'secrecy, being an instrument of conspiracy, ought never to be the system of a regular government' (Bentham and Bowring, 1843). Any government, if functioning in secret, might tend to abuse power. Thus, FOI law is crucial because of its provision of legal guarantees of the right to access information, which enhances accountability by empowering the public to monitor the decision-making processes undertaken by state agencies (Hood and Heald, 2006).

Public scrutiny and government accountability was regarded as 'the principal inspiration' of the United States' FOI Act in 1966 [Cate et al. (1994), p. 42]. The theoretical framework forming the law derived from the idea of American statesman James Madison. He held that a 'popular government' shall provide 'popular information' to the public because 'knowledge will forever govern ignorance' (Madison, 1822). The famous statement of an American lawyer and associate justice in the Supreme Court of the United States, Louis Dembitz Brandeis, that 'sunlight is said to be the best of disinfectants', was considered the ideological foundation for the introduction of FOI law (Louis, 1914).

Similar to the United States, in Australia, public scrutiny and accountability have been considered by the Senate Standing Committee on Constitutional and Legal Affairs as a reason for the passage of the FOI Act in 1982:

\begin{abstract}
We believe that when government is more open to public scrutiny, it in fact becomes more accountable. As a result there is a greater need for it to be seen as efficient and competent. The accountability of the government to the electorate, and indeed to each individual elector, is the corner-stone of democracy, and unless people are provided with sufficient information accountability disappears [Senate Standing Committee on Constitutional and Legal Affairs (1979), para(s) 3-4].
\end{abstract}

\subsubsection{FOI as a tool of the efficiency of public administration}

In countries where the FOI has been enacted after 2000, particularly developing ones, accountability is no longer the most fundamental ground underpinning FOI legislation (Banisar, 2006). In developing countries, the World Bank advocated for the passage of FOI law by emphasizing the role of FOI in the effectiveness of state management [Lemieux and Trapnell (2016), p.2]. FOI has been identified as necessary for the efficiency of public administration for two reasons. 


\section{Dang Trung $\mathrm{Ha}$}

Firstly, the access to information helps citizens and social organizations have the opportunity to evaluate policy initiatives in multiple levels and raise their voice on drafts of policies and legislation. The process in which the government and its agencies provide information to the public facilitates social readiness and informed preparations of the people and the entities affected by the implementation of new policies. Consultation and decision-making processes take into account both supportive and unsupportive comments so that the policy makers are able to foresee any irrationality and inconsistance when considering approval of a new policy. While policies are always the products of bureaucracies for their purposes of public administration, political and social consensus crucially constitutes the success of any policies. Once the consensus is significantly achieved during early stages of policy initiatives and public consultations as well as necessarily upheld throughout the policy circle, the level of people's satisfaction will be positive (Grimmelikhuijsen et al, 2013).

Secondly, FOI is a contributor to reducing negative aspects of institutional and operational activities such as government corruption or state power abuse. Many organizations and international experts confirm that FOI law is the most essential weapon in the cause of anti-corruption (Banisar, 2006). FOI law, on the one hand, is said to play a crucial role in the battle against corruption simply because corruption is rooted in a lack of transparency regarding the operations of the state apparatus, while FOI laws aim at ensuring transparency and the citizens' supervision of the activities undertaken by the public agencies and public officials (Heald, 2006). On the other hand, FOI law brings the advantage of curbing abuse of state power as the disclosure of activities along with public supervision restricts the possibility of abusing power and concealing illegal acts. Stiglitz, an economic Nobel prize winner in 2011, argues that FOI has an outstanding role to play in reducing the asymmetry of information, which takes place in the relationship between the state and its citizens, consequently enhancing the efficiency of government operations (Stiglitz, 2002).

China demonstrates the role of an FOI regime in improving the public administration for economic development (Xiao, 2013). The introduction of Regulations on Open Government Information in 2007 provides evidence of FOI legislation regardless without accountability. According to Xiao, the FOI law of China should be examined "within the context of improved information flow resulting from changed social, political, legal and economic conditions." [Xiao (2013), p.2]. FOI law has been initiated from the most crucial need that the administrative reform and the capacity of administrative systems must be strongly enhanced while government was facing a boom of information sources in the society. Focusing on economic reform, China also approached the challenge of improving the administration in order to promote the development of economy. FOI reform thus commenced as an integration of law reform and administrative improvement in order to meet concurrently the requirements of economic developments, political stability, and leadership of the Communist Party of China (Xiao, 2013).

\subsubsection{FOI as a tool for meeting requirements of globalisation}

The worldwide diffusion of FOI law after in the 2000s reveals changes in the foundation of FOI legislation which originally was for accountability (Roberts, 2006). FOI law in the 21 st century can be enacted in a country in any region of the world, not only in 
Western developed countries like the United Kingdom but also and in small African developing countries such as Togo (Freedominfo.org). Globalisation has arguably influenced the enactment of FOI legislation in countries after 2000 as a result of multilevel influences when countries were actively learning about, passively convinced of the benefits of, or under external pressure to adopt, the laws on FOI (Banisar, 2006; Lidberg, 2006; Roberts, 2006). Countries tend to learn others' policies while facing challenges caused by globalisation (Xiao, 2013). Learning about the model of the United States has influenced the adoption of FOI laws in many countries despite the difference in social and cultural context [Lamble (2003), p. 66]. Moreover, the advocacy of international nongovernmental organisations ('INGOs') has resulted in the adoption of FOI laws. According to Berliner, the links between INGOs and local civil society groups in the cause of globalisation made significant contributions to the enactment of FOI law in developing countries after 2000 (Berliner, 2016).

The pressure in many cases comes from the desire of democracy that FOI law may bring about. According to Lidberg, FOI laws in the $21^{\text {st }}$ century have been considered to be a symbol of democracy, and 'a country must show that it supports the notion of transparency and openness in governance [at least in theory] by adopting FOI laws' [Lidberg (2006), p. 42]. FOI law has become an icon of transparency and open government; therefore, a country must "possess" its own FOI law to show it is willing to manifest the country's support and desire of transparency (Lidberg, 2006). This indicates the momentum by which many developing countries, which had not been known for traditional democracies, have proactively joined the list of countries adopting an FOI regime.

\title{
4 Distance from Theory to Practices
}

\subsection{The variation of protecting the right to access state-held information}

\author{
under FOI laws
}

Although FOI Law has been defined as the regime to ensure the right of individuals to access information held by public bodies, the scope of the right protected under FOI laws varies in different countries (Ackerman and Sandoval-Ballesteros, 2006). Ackerman and Ballesteros argue that 'each country has developed its own organic understanding of what FOI means conceptually and what FOI requires in practice' [Ackerman and SandovalBallesteros (2006), p.95]. The human rights standards for access to state-held information, therefore, are also adhered to in varying degrees in the FOI laws of nations. For example, according to RTI Rating ${ }^{8}$, of the 111 countries those have adopted FOI laws up to 2017, only 56 countries grant the right of access to information for 'everyone'. Similarly, only 37 and 42 countries allow access to the information of the judicial and legislative bodies respectively.

FOI laws around the world also vary in terms of exemptions. Although information disclosure under HRBA can be theoretically exempted only if it matches the conditions of the public interest test, many of the FOI laws 'do not include such [a] rigorous test' 1 


\section{Dang Trung $\mathrm{Ha}$}

(Ackerman and Sandoval-Ballesteros, 2006). In particular, countries differ in their ways of initiating necessary balances within FOI legislation. For example, the FOI law in United Kingdom provides a list of 'absolute exemption', which allows to not disclose some kind of information without any consideration (Freedom of Information Act 2000 (UK), s 2.). The FOI law in China creates an exception for 'social stability in the release of government information', which is quite broad and unclear.

The difference in levels of legal interpretation provided to the right to access information raises a question about the real objectives of the FOI law. If the law is aimed at ensuring the right of individuals to access information, why is the right not identically guaranteed or based on unified principle? It argues that the rationales underpinning FOI laws which support the enhancement of instrumental values have significantly impacted the scope of the right to FOI.

\subsection{The influence of instrumental approaches}

Conceptualising the rights to access state-held information as secondary to values of FOI laws influences the scope of the right which is guaranteed. FOI law, under this conceptualisation, can assist the bureaucracies in controlling what information they want to release.

First, the objective of the FOI law determines the level of disclosure. That explains why countries have defined the scope of the right to FOI differently (Ackerman and Sandoval-Ballesteros, 2006). Australia's FOI Act 1982 is an example of this impact. Because of the main role of furthering accountability of executive bodies, Australia's Freedom of Information Act 1982 (Cth) stipulated that obligations of the public disclosure related to information on 'administrative matters' only. ${ }^{10}$ The right to access to information pursuant to the law also does not cover the documents issued by the Cabinet because this body is traditionally obliged to reporting to the Parliament in accordance with the Westminster system and thus is not required to disclose information to the public (Upcher and Snell, 2002). In addition, the rationale in relation to accountability has significantly driven the provisions of the Freedom of Information Act 1982 (Cth) on the list of '[e]xempt agencies'"11, whose accountability schemes were supposedly equivalent replacements for responsibilities under the FOI regime.

In the case of China, the motivation of administrative reform leads to FOI regime being considered as a tool of propaganda. "It's FOI, but not as we know it" (Snell and Xiao, 2007). Provisions on proactive disclosure prevail in Regulations on Open Government Information 2007 while reactive disclosure is practically restrained (Xiao, 2013). FOI in China has not truly enhanced the citizens' right to access information although this supposed administration tool has increased the level of public disclosure. The increase in the level of publicity is arguable to meet the needs of the state rather than the demands of citizens (Stubbs and Snell, 2014).

Second, the requirement of international organisations in the context of globalisation can not only have a positive effect on the diffusion of FOI Law worldwide, but can also challenge the development of FOI Law. Banisar discusses this global diffusion: 
Many of the laws are not adequate and promote access in name only. In some countries, the laws lie dormant due to a failure to implement them properly or a lack of demand. In others, the exemptions are abused by governments [Banisar (2006), p. 66].

Roberts holds that the adoption of FOI law with the significant impact of globalisation has led to the fact that a country does not engage in any "ownership" in respect of its FOI regime (Roberts, 2006), and consequently the significant gaps between the law in "text" and the law in "practice" (Hazell and Worthy, 2010). A country which has adopted strong FOI law may not guarantee the right to access to information better than other countries (Trapnell, 2014).

\subsection{Misleading on function of FOI laws}

The historical diffusion of FOI law around the world shows the gap in knowledge of a firm theory to underpin FOI law [Calland and Bentley (2013), p. 570].The wide range of different approaches to FOI has led to a number of diverse ways of conceptualising FOI. Stubbs and Snell define FOI law as an 'empty signifier' based on the contextual conditions and rationales pursuant to which the law on FOI is enacted:

The meaning of the term 'FOI' is to a large degree filled within the context of a particular adopter or advocate. The term can be thought of as a 'floating concept' or 'empty signifier', because the object the term signifies is relative. FOI, like democracy, may be thought of as an 'essentially contested concept' [Stubbs and Snell (2014), p. 150].

FOI law, under this conceptualisation, focuses on a range of possible objectives for FOI. The weaknesses of instrumental approaches causes significant differences in the scope of legal guarantees for the right to access state-held information under FOI laws (RTI Rating, 2017). From their own goals of government transparency, countries identify different 'standards' for access to public information. These standards, again, vary from country to country because of their dependence on political, social, economic and cultural contexts of respective countries. Thus, this approach assists a state in its decision-making process for adopting laws and may leads to a defective interpretation of FOI laws. The approach can even cause a converse impact on the fundamental values of FOI law when it does not help further legal guarantees to the right to access information but prevents people from exercising their respective rights. For example, Zimbabwe enacted FOI regime which includes a number of provisions for exemptions in order to limit the right to access information (Banisar, 2006). It is unacceptable to introduced FOI laws with the goal to reduce or even work against the intrinsic values of the right to access state-held information. The above mentioned weakness of the instrumental approach hinders the schemes that base FOI legislation on the government interest rather than the benefits of the people. So, if it is an 'empty signifier', is it a matter for state determination whether it shall limit the people's right to access information held by its public agencies?

\section{Conclusion}

It is not a coincidence when advocates mount campaigns to support FOI as a human right. FOI, when being addressed as a human right, creates opportunities for individuals to enjoy their freedom of searching for information to meet their own needs rather than wait 


\section{Dang Trung $\mathrm{Ha}$}

for the willingness of governments to provide it [Sebina (2006), p.113]. Taking this perspective of human rights, states are obligated to implement this right through stipulations on legal procedures and archive systems. A human rights rationale endorses the intrinsic value of FOI laws and gives a justification for the obligation of the state to disclose information.

The view of FOI laws within the HRBA also contributes to a significant change, which empowers citizens, not bureaucracies, to determine which types of information are to be publicized. The change allows individuals to make decisions regarding the information that they want while state agencies are placed in the position that public disclosure is a 'must' even when such openness harms the reputations of respective state bodies. FOI law, thereby, plays an important role in defining principles and standards, mandating state agencies to properly perform their duties to guarantee the citizens' right to access state-held information. The HRBA enables a theoretical framework of understanding FOI law as a legal requirement for the state to respect, protect and fulfil its obligations regarding the right of every person to access state-held information. HRBA, however, has been distorted by 'more instrumental, pragmatic grounds' [Ackerman and Sandoval-Ballesteros (2006), p. 92], which have focused on objectives other than the supposedly fundamental goal of protecting the right.

The global development of FOI shows the law can be tied to accountability, improvements in the operational efficiency of administrative systems or just to the 'rite of passage' which shows that the state is in favour of transparency and openness in government (Lidberg, 2006). The instrumental approach to FOI leads to different levels of public disclosure because bureaucracies can choose to use FOI law as a tool for different objectives.

FOI law is a 'political creature' [Ackerman and Sandoval-Ballesteros (2006), p. 119] and is significantly dependent upon a willingness of the politicians throughout all stages of the policy-making process to implement the law in accordance with the human rights standards of FOI. The willingness of legislative decision-makers varies according to social, economic, political, historical and cultural incentives during certain time periods, and thus diverse influences on how the FOI law is introduced:

Although the freedom of information narrative requires an emphasis on its universal character, it has been the specific and local nature of political and a social struggle that has determined the impact of each law passed. This insight has been given insufficient weight in the literature [Darch and Underwood (2009), p. 156].

To understand what factors affect the struggle for the right of access to state-held information, scholars need not only to recognise the universal human rights of FOI but also to understand 'the real world' of FOI in its comprehensively local contexts. Further studies on other pluralist approaches, which articulate 'unity-in-diversity' (Messer, 1997) to FOI laws, should be very interesting. 


\section{References}

Ackerman, J.M. \& Sandoval-Ballesteros, I.E. (2006) 'The global explosion of freedom of information laws', Administrative Law Review, vol. 58, no. 1, pp. 85-130.

Banisar, D. (2006) 'Freedom of information around the world 2006: A global survey of access to government information laws', Privacy International.

Barak, A. (2012) Proportionality: constitutional rights and their limitations, Cambridge University Press.

Bennett, C.J. (1997) 'Understanding ripple effects: the cross-national adoption of policy instruments for bureaucratic accountability', Governance, vol. 10, no. 3, pp. 213-33.

Berlin, I. (1958) 'Two concepts of liberty', Clarendon Press Oxford.

Berliner, D. (2016) 'Transnational advocacy and domestic law: International NGOs and the design of freedom of information laws', The Review of International Organizations, vol. 11, no. 1, p. 121.

Birkinshaw, P. (2006) 'Freedom of information and openness: Fundamental human rights?', Administrative Law Review, vol. 58, no. 1, pp. 177-218.

Bishop, C.A. (2011) Access to information as a human right, LFB Scholarly Publishing LLC.

Bouhadana, I. (2016) 'The right of Access to Public Information: An Analysis of International Conventions', Revue Internationale des Gouvernements Ouverts, Vol. 2 (2015), pp. 1-10.

Boutros-Ghali, B. (1995) 'Address by the Secretary-General of the United Nations at the Opening of the International Conference on Population and Development', St. LouisWarsaw Transatlantic LJ, p. 1.

Calland, R. \& Bentley, K. (2013) 'The impact and effectiveness of transparency and accountability initiatives: Freedom of information', Development Policy Review, vol. 31, no. s1, pp. s69-s87.

Cate, F.H., Fields, D.A. \& McBain, J.K. (1994) 'The right to privacy and the public's right to know: The" central purpose" of the Freedom of Information Act', Administrative Law Review, vol. 46. Winter 1994, pp. 41-74.

Clayton, R., Tomlinson, H. \& George, C. (2000) The law of human rights, vol. 2, Oxford University Press, USA.

Copper, J.F. (1994) 'Peking's Post-Tienanmen Foreign Policy: The Human Rights Factor', Issues \& Studies, vol. 30, no. 10, pp. 49-73.

Darch, C. \& Underwood, P.G. (2009) Freedom of Information and the Developing World: The citizen, the state and models of openness, Elsevier.

Donders, Y. (2015) The United Nations and Freedom of Expression and Information, Cambridge University Press.

Donnelly, J. (2007) 'The relative universality of human rights', Human Rights Quarterly, vol. 29 , no. 2 , pp. 281-306.

Freedominfo.org, Chronological and Alphabetical lists of countries with FOI regimes., viewed 27 June 2017, <http://www.freedominfo.org/?p=18223>. 
Dang Trung Ha

Freedominfo.org, FOI Countries by Date http://freedominfo.org/, viewed 27 June 2017, $<$ http://freedominfo.org/>.

Freeman, M. (2011) Human rights: an interdisciplinary approach, Polity.

Grimmelikhuijsen, S., Porumbescu, G., Hong, B. \& Im, T. (2013) 'The Effect of Transparency on Trust in Government: A Cross-National Comparative Experiment', Public Administration Review, vol. 73, no. 4, pp. 575-86.

Hazell, R. \& Worthy, B. (2010) 'Assessing the performance of freedom of information', Government Information Quarterly, vol. 27, no. 4, pp. 352-9.

Heald, D. (2006) Transparency as an instrumental value, Oxford University Press for The British Academy.

Hood, C. \& Heald, D. (2006) Transparency : the key to better governance?, Oxford University Press, Oxford ; New York.

Human Rights Committee (2011), 'General comment No. 34, Article 19: Freedoms of opinion and expression', no CCPR/C/GC/34.

La Rue, F. (2011) 'Report of the Special Rapporteur on the promotion and protection of the right to freedom of opinion and expression.'.

Lamble, S. (2003) 'United States FoI laws are a poor model for statutes in other nations', Freedom of Information Review, vol. 106.

Lidberg, J. (2006) "Keeping the bastards honest': the promise and practice of freedom of information legislation', Murdoch University, Western Australia

Louis, D. (1914) 'Brandeis, What Publicity Can Do, harper's wkly., Dec. 20, 1913, reprinted in louis D', Brandeis, Other People's Money and How the Bankers Use It, vol. 92 , p. 92.

Madison, J. (1822) 'Letter to WT Barry, August 4, 1822', [online] http://oll.libertyfund.org/titles/madison-the-writings-vol-9-1819-1836, (accessed 17 September 2017).

Mathiesen, K. (2008) 'Access to information as a human right', Available at SSRN 1264666.

McDonagh, M. (2013) 'The Right to Information in International Human Rights Law', Human Rights Law Review, vol. 13, no. 1, pp. 25-55.

Messer, E. (1997) 'Pluralist approaches to human rights', Journal of Anthropological Research, vol. 53, no. 3, pp. 293-317.

Mill, J.S. (1869) On liberty, Longmans, Green, Reader, and Dyer.

Mustonen, J. (2006) The world's first freedom of information act: Anders Chydenius' legacy today, Anders Chydenius Foundation.

Organization of American States (2012) The right to access to information in the Americas: Inter-American standards and comparison of legal frameworks, $<$ https://www.oas.org/en/iachr/expression/docs/publications/access $\% 20$ to\%20informa tion\%20in\%20the\%20Americas\%202012\%2005\%2015.pdf>.

Renteln, A.D. (2013) International human rights: universalism versus relativism, Quid Pro Books, New Orleans, Louisiana. 
The false promise of HRBA to FOI laws

Roberts, A. (2006) Blacked out: Government secrecy in the information age, Cambridge University Press, New York.

Rodan, G. (2004) Transparency and authoritarian rule in Southeast Asia: Singapore and Malaysia, Routledge.

RTI Rating (2017) Global Right to Information Rating, viewed 3 July 20172017 , <http://www.rti-rating.org/>.

Sebina, P. (2006) 'Freedom of Information and records management: a learning curve for Botswana', University of London.

Sen, A. (1997) 'Human rights and Asian values', paper presented at the Sixteenth Morgenthau Memorial Lecture on ethics and Foreign Policy sponsored by the Carnegie Council on Ethics and International Affairs. p.17.

Senate Standing Committee on Constitutional and Legal Affairs 1979, Freedom of Information (Canberra, 1979).

Shue, H. (1996) Basic rights: Subsistence, affluence, and US foreign policy, Princeton University Press, New Jersey.

Stiglitz, J. (2002) 'Transparency in government', The right to tell: The role of mass media in economic development, pp. 27-44.

Stubbs, R. (2012) 'A case study in the rise of public sector transparency: Understanding the global diffusion of freedom of information law', University of Tasmania.

Stubbs, R. \& Snell, R. (2014) 'Pluralism in FOI Law Reform: Comparative Analysis of China, Mexico and India', U. Tas. L. Rev., vol. 33, p. 141.

The Article 19 (2007) 'Access to Information: An instrumental right for empowerment', London, <https://www.article19.org/data/files/pdfs/publications/ati-empowermentright.pdf>.

Upcher, J. \& Snell, R. (2002) 'Freedom of information and parliament: A limited accountability tool for a key constituency?', Freedom of Information Review, vol.2002, no. 100 , p. 35 .

Vienna Declaration and Program of Action, adopted by the World Conference on Human Rights, Vienna, 14-25 June 1993, UN Doc A/CONF.

Worthy, B. (2017) The politics of freedom of information: how and why governments pass laws that threaten their power, Manchester University Press, Manchester.

Xiao, W. (2013) Freedom of Information Reform in China: Information Flow Analysis, vol. 10, Routledge, London and New York.

\section{Notes}

P. Bayne (1984) 'Freedom of Information', Legal Service Bull., Vol. 9, pp. 121 (Access 1984).

A. Florini (2007) The right to know : transparency for an open world, Columbia University Press, New York. Table of contents only http://www.loc.gov/catdir/toc/ecip073/2006036068.html. Access 2007). 
Dang Trung Ha

${ }^{1}$ FOI law(s) in this article refers to the legal document with different names, such as 'Freedom of Information Act', 'Law on Access to Information' or 'Right to Information Act' or 'Official Information Act', etc. All of them have been promulgated in order to give individuals the right to access information held by public authorities.

${ }^{2}$ International Covenant on Civil and Political Rights, opened for signature 16 December 1966, 999 U.N.T.S. 171 (entry into force 23 March 1976), art. 19.

3 American Convention on Human Rights (Adopted at the Inter-American Specialized Conference on Human Rights, San José, Costa Rica, 22 November 1969).

${ }^{4}$ Claude Reyes et al v Chile [2006] IACHR Series C no 151 (19th September 2006), para 77.

5 Ozgur Gundem v. Turkey [2000] ECHR (16 March 2000), para 43.

${ }^{6}$ Claude Reyes et al $v$ Chile [2006] IACHR Series C no 151 (19th September 2006), para 58.

${ }^{7}$ For example, Australia's Freedom of Information Act 1982 includes a list of agencies exempted from the obligations to provide the public with their holding information. Similarly, the United Kingdom's Freedom of Information Act 2000 also states a list of exceptional bodies, which often function in the areas concerning the public security and national defense like the intelligence offices. From the perspective of human-rights based approach, the common justification for such exemptions in order to ensure the effectiveness of those agencies' functions is hardly acceptable.

${ }^{8}$ RTI Rating was built up by the Access Info Europe (AIE) and the Centre for Law and Democracy (CLD), which are two non-governmental organizations in the sector of promoting human rights, in consultations with 79 experts worldwide, and released in September 2011. The most central application of the RTI Rating is a tool of measures through 61 Indicators to reflect 'the quality of the world's access to information laws'. Available at $<\mathrm{http}: / / \mathrm{www}$.rti-rating.org/>.

9 Ordinance on Openness of Government Information 2007 (China). English version available at $\langle$ http://www.rti-rating.org/wp-content/uploads/China.pdf>, art.8.

10 For example, Sect 6 of the FOI Act 1982 (Cth) states: "this Act does not apply to any request for access to a document of a tribunal, authority or body so specified unless the document relates to matters of an administrative nature."

11 The Freedom of Information Act 1982 (Cth), Schedule 2. 